\title{
How to measure the unmeasurable: Project Grey developing capacities and capabilities for tackling undeclared work
}

\author{
Predrag Bejaković \\ Institute of Public Finance, Zagreb, Croatia \\ predrag.bejakovic@ijf.hr
}

\begin{abstract}
The term "not directly observed" or "the underground economy" refers to those economic activities that should be included in the GDP estimation but which are not recorded in the statistics business surveys or tax and administrative data used in the calculation of the estimates of national accounts because they are not directly observable. The unofficial or informal economy contains that part of the economic activity that is difficult to measure. Thus, in addition to the complex issue of defining the underground production, there is an even more demanding task of measuring it. Hitherto in the literature, various estimation methods of unofficial economy have been proposed and their results differ significantly. The goal of this article is to provide an overview of the various methods of its measurement. The unobserved economy poses estimation problems of economic aggregates that can be differentiated as the total lack of information and the distortion of available information. There is no universal optimal approach applicable to all countries or even to the same country at different periods. In the attempt to limit the underground economy, it is much better to obviate the causes than penalise the consequences. It is necessary to simplify the procedures enabling citizens to formalize their undeclared activities, to provide a tax system that is as stable as possible and a tax and regulatory burden that is as low as possible. What is crucial is the improvement of institutions, professionalization of civil service and removal of the huge impact of politics in the societies.
\end{abstract}

Keywords: causal methods, direct methods, economic policy, Eurostat approach, indirect methods, measurement of underground economy.

JEL classification: $\mathrm{E} 26, \mathrm{H} 26, \mathrm{O} 17$

DOI: 10.1515/crebss-2017-0007

Received: October 05, 2017

Accepted: December 22, 2017

Acknowledgments: This paper is an output of the European Commission's Framework 7 Industry-Academia Partnerships Programme (IAPP) grant no. 611259 entitled 'Out of the shadows: developing capacities and capabilities for tackling undeclared work in Bulgaria, Croatia and FYR Macedonia' (GREY). The authors would like to thank the funders for providing the financial support to enable the research and writing of this paper. The usual disclaimers apply. 


\section{Introduction}

Institute of Public Finance, Zagreb with project partners Centre For The Study Of Democracy, Sofia and University of Sheffield realised EU Marie Curie IndustryAcademia Partnerships and Pathways (IAPP) four-year Project 'Grey - Out of the Shadows: Developing capacities and capabilities for tackling undeclared work in Bulgaria, Croatia and FYR Macedonia'. The goal of the Project is to provide concrete recommendations for policy measures, based on hard empirical evidence, for the stakeholders seeking to tackle the informal economy in these three observed countries.

The term informal economy refers to those economic activities that should be included in the GDP estimation but which are not included in the statistics business studies or tax and administrative data sources used in the calculation of the approximations of national accounts because they are not directly visible. Based on international definitions (OECD, 2002, p.13), "underground production, defined as those activities that are productive and legal but are deliberately concealed from the public authorities to avoid payment of taxes or complying with regulations". Here is also illegal production, deemed as those industrious activities that produce goods and services prohibited by law or that are illegal when carried out by illicit producers as well as unofficial sector production. These are productive activities performed by autonomous enterprises that are not registered and/or are smaller than a specified magnitude in terms of employment. Finally, here is also included the production of households for their own final use, defined as activities that produce goods or services for own consumption.

Non-observed economy next to the underground economy contains also business activities related to: 1) illegal activities; 2) production of the informal sector; 3) inadequacy in statistical system. Illegal activities are both the production of goods and services whose trade, delivery or possession is prohibited by law, and those activities that, while legal, are performed by unlawful operators (for example, abortion performed by unlicensed medical practitioners). All other productive activities defined by national accounting systems are legal.

As opposed to formal contracts, informal activities are the legal productive activities carried out on a small scale, with low levels of organization, with little or almost no division between capital and labour, with labour relations based on casual employment and/or personal or family relationships. The legal productive activities exclusively not recorded for deficiencies of the statistical data collection system, such as the failure to update the archives of the companies or failure to complete the administrative forms and/or statistical questionnaires aimed at businesses survey, are undeclared (submerged, hidden) statistic. What is commonly known as submerged economy, in international definitions often coincides with the underground (grey) economy, i.e., with the set of legal productive activities that do not respect tax rules and payment of social contributions in order to reduce production costs.

The underground (grey) economy should not be confused with the term the informal economy, what is not a synonym for the activities hidden from the tax authority, because it refers to the structural aspects of productive activity and not to the intention to evade tax and contribution obligations. Informal activities are included into total of the non-observed economy because of their nature; it is difficult to detect them directly. Figure 1 presents and explains the various forms of the informal economy. 


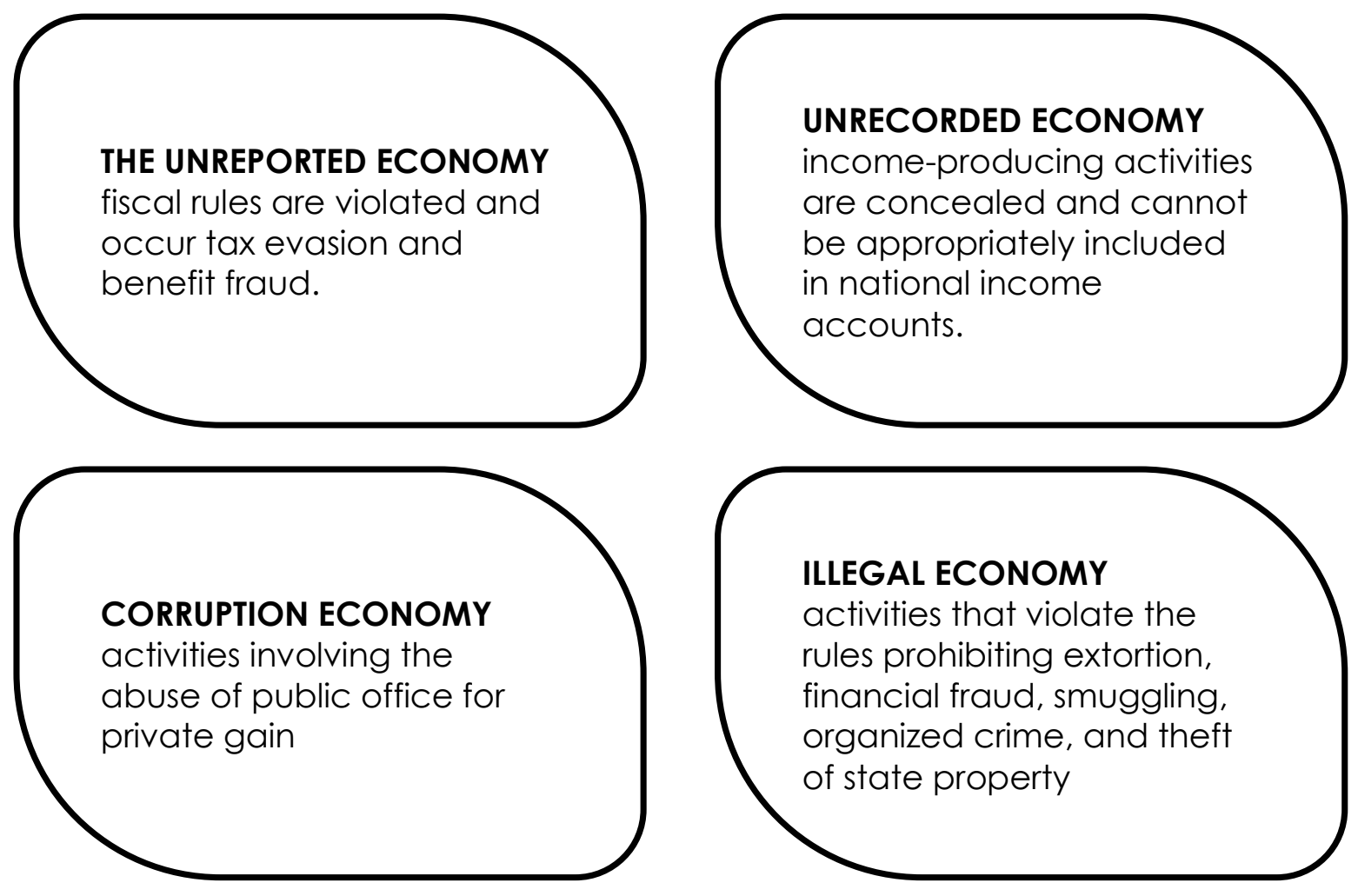

Source: Feige, 1990.

Figure 1 Typology of the informal economy

The informal economy encompasses that part of the economic activity that is hard to measure. Thus, next to the complex nature how to define the underground production, there is even more demanding task how to measure it. Hitherto in the literature, various estimation methods of unofficial economy have been proposed and their results differ significantly. The goal of this article is to provide an overview on the various methods of its measurement. This will be shown on the example of the mentioned Project 'Grey - Out of the Shadows'. After this introduction notes, in the following chapter related problems and various methods are presented having in mind their advantages and disadvantages. The next part is dedicated to the methods applied in the mentioned Project and their most important results. The final chapter contains conclusions and recommendations for the further researches.

To understand these startling variations, next chapter evaluates the array of techniques used to estimate the size of the unofficial economy. These models range from direct to indirect measurement methods (for reviews, see Bajada, 2002, Smith, Wied-Nebbeling, 1986, OECD, 2002, Galić Nagyszombaty, 2012, Thomas, 1988, 1992, Schneider, Enste, 2002).

\section{Related problems and various methods of measuring the underground economy}

In this part of the text, an overview of the various problems and methods for estimation of the unofficial economy is given. The unobserved economy poses estimation problems of economic aggregates that can be divided in two main types: 1) total lack of information, and 2) distortion of available information.

The former group includes the existence of unregistered production activities, the failure to update the records of the production units, the business entity did not 
respond to statistical surveys, the concealment of employment by enterprises (moonlighting) and related aggregates (production, value added, wages). The second group includes the companies' under-declaration of the production and the value added obtained by regular employees.

The methods used in obtaining comprehensive assessments of economic aggregates are mainly the following:

a) application of a revaluation model for value added declared by small and medium-sized enterprises;

b) comprehensive estimation of labour input by means of the integration of information of statistical sources and directly observable administrative sources, as well as the use of sources of information and statistical techniques that make possible estimation of irregular employment;

c) use of comprehensive employment estimates (point b) as expansion coefficients of the average values per capita measured through surveys of firms accounts and adjusted for underreporting;

d) verification of the consistency of the economic aggregates with techniques of balancing resources and uses (investment) at the level of single branch of economic activity.

The estimation approach of the branch aggregates (production, value added, intermediate costs, investments and employees' salaries) through the labour input, ensures the coverage of all regular working positions in the field of observation, and also allows overcoming the problems related to the "lack of information". These problems are due to either lack of basic statistical system (submerged statistical) or total concealment of employment and value added for reasons of tax and social contribution evasion (underground or submerged economy). Consistency checks between the data reported by the companies aim to correct the partial concealment, again for tax reasons, the achieved turnover with the declared employment and the over-declaration of costs.

The process of reconciliation of the aggregate supply of goods and services (domestic or internal production, imports) and aggregate demand (consumption, investment, exports, changes in inventories and valuables), through balancing techniques. They take into account the different reliability of the various aggregates also in relation to their sensitivity to concealment. Mentioned process has the function to make further additions to the estimates of the aggregates (ISTAT, 2016).

In most cases, the distinction between the official and unofficial economy is quite demanding. These two parts are interconnected and interlaced even in highly developed market societies. Feige and Urban (2008) give probably the most useful definition of overall economic activity as the sum of an observed and imputed unobserved component:

$$
Y=Y R+Y U R=Y R O+Y I U I+Y U R
$$

Where $Y=$ total economic activity (TEA), $Y^{R}=$ recorded economic activity (measured output; GDP), YRO = recorded observed economic activity, YIUI = recorded unobserved economic activity, and YUR = unrecorded activity.

Feige and Urban (2003) define the total amount of the unobserved economy (YU) as the sum of recorded and unrecorded unobserved income.

There are numerous methods for an estimation of the size of the unofficial economy. They can be divided into direct and indirect methods, causal methods and Eurostat approach. In this part of the text, an overview of the various methods for estimation of the unofficial economy. Some of them are more appropriate to the developed countries while others are more adequate for estimation of UE in post-transition economies. Galić Nagyszombaty (2012) rightly underlines that according to the 
numbers of approaches applied by different researchers, and the diversity of their views, one can state that there is no universal optimal method capable of being applied to all economies or even to the same economy at different periods.

Table 1 Various methods of an estimation of the size of the unofficial economy

\begin{tabular}{|c|c|c|c|}
\hline Direct methods & Indirect methods & Causal methods & Eurostat approach \\
\hline $\begin{array}{l}\text { Questionnaires by } \\
\text { post, mail or Web }\end{array}$ & $\begin{array}{l}\text { A macro approach - } \\
\text { Difference between } \\
\text { revenues and } \\
\text { expenditures. }\end{array}$ & $\begin{array}{l}\text { Determinants and } \\
\text { indicators- } \\
\text { DYMIMIC }\end{array}$ & $\begin{array}{l}\text { Exhaustiveness of } \\
\text { national accounts }\end{array}$ \\
\hline $\begin{array}{l}\text { Face to face and } \\
\text { telephone } \\
\text { interviews }\end{array}$ & $\begin{array}{l}\text { A micro discrepancy } \\
\text { approach - } \\
\text { Difference between } \\
\text { receipts and } \\
\text { expenditures }\end{array}$ & Demand for cash & \\
\hline $\begin{array}{l}\text { Focus group } \\
\text { discussions }\end{array}$ & $\begin{array}{l}\text { Labour market } \\
\text { approach by } \\
\text { comparing the } \\
\text { activity rates }\end{array}$ & & \\
\hline $\begin{array}{l}\text { Detail control of tax } \\
\text { returns and use of } \\
\text { tax statistics }\end{array}$ & Cash in circulation & & \\
\hline $\begin{array}{l}\text { Experts' estimation } \\
\text { on the situation in a } \\
\text { particular economic } \\
\text { sector }\end{array}$ & Transaction method & & \\
\hline $\begin{array}{l}\text { The share of very } \\
\text { small enterprises }\end{array}$ & $\begin{array}{l}\text { Use of physical inputs } \\
\text { method, like } \\
\text { electricity }\end{array}$ & & \\
\hline
\end{tabular}

Source: Easton, 2001, Schneider, Enste, 2000, Galić Nagyszombaty, 2012, OECD, 2002, Schneider, 2005, 2012, Smith, Wied-Nebbeling, 1986.

Table 1 presents four groups of various methods of an estimation of the size of the unofficial economy.

\section{Direct methods}

Mail back of self-completion questionnaires is the most efficient collection method for some type of interviewed persons or for many enterprise surveys. Both the mail communication may be by regular post, fax and/or e-mail depending on the preferences of the interviewed persons. For enterprise questionnaires containing a limited set of questions and variables, realised directly by telephone may be possible and quicker, though usually more costly. Typically, these questionnaires ask direct questions based on whether or not the interviewed persons have ever received black money for a job or service and information on the amount of unreported income. However, such methods usually underestimate the size of the informal economy as interviewed persons most likely do not state precisely or understate their participation in the informal economy, so it is possible to obtain lower bound estimates (Easton, 2001). The main advantage of this method is the possibility to obtain detailed information about the structure of the shadow economy. Of course, the result of these kinds of surveys depends on how the questionnaire is formulated. The main disadvantage of the method is that results and average precision greatly depend on the willingness of the respondents to cooperate. Most interviewed persons hesitate to confess the illegal or immoral activities and obtained responses 
are almost never reliable. Thus, it is difficult from these types of questionnaires to achieve a real and relatively reliable estimation of the undeclared work.

Face to face interviews are generally unsuitable although they may be used in the collection of demanding and/or unpleasant information, for example in relation to participation in the underground economy. Rapid advancement in electronic processing and communications technology means that the vital goal of automated data collection, direct from private or enterprise computer to statistical office computer, may be possible very soon, but of course there is the issue of a privacy and/or business secrets. For household surveys, face to face or telephone interview is more frequently appropriate than mail questionnaires. However, there is an important issue of the questionnaire's design that has a substantial impact on response rates and occurrence of misreporting. Questionnaire design is a specialised and complex expertise, involving knowledge of accounting practices, of the cognitive reactions of interviewed persons (how they understand questions), and of succeeding data proceeding (how easily and successfully statistical office staffs are able to convert the replies into needed electronic form).

Focus group discussions and interviews can be useful in obtaining hidden problems of the unofficial economy. For example, Roever (2014) used focus groups in the analysis of informal street vendors in 10 cities in different undeveloped countries. She recognised the lack of a secure workspace, evictions, and relocations as noteworthy causes. Obtained quantitative data validated that insecure workplace conditions affect many vendors, especially those who work in the streets rather than in market. However, the obtained results have to be explained carefully, particularly for those surveys focussed on sensitive subjects. For example, in surveys relating to tax evasion, it is very likely that the non-response is selective because people who are inclined to the tax evasion are more likely not to participate and/or report honest behaviour.

Detail control of tax returns or audit method uses personal tax returns for different income groups, and audits them carefully to identify those who are misreporting their actual income. This method drastically understates the size of the informal economy as it only measures tax evasion and does not include production and distribution of illegal goods and services. It has been used by the US Internal Revenue Service (1979) where a sample of 50,000 income tax returns was very thoroughly examined and compared with data available from information returns completed by payers of personal income tax. Approximately $25 \%$ of the incomes that were reported in the information returns were not mentioned on the tax returns. Kazemier (1991) realised a similar research on concealed interest income on giro, bank and savings accounts in the Netherlands. Swedish Tax Administration Office (Riksstatteverk) performed a detail control of tax returns and assessed that unregistered was 8 to $15 \%$ of realised income (Hansson, 1980). Hansson (1982) later with econometric analysis concluded that mentioned share was lower, in total amount of around 3.8\% of earned income. The weakness of this method is that individual respondents who have a very small amount of income do not exceed the required "threshold" for paying taxes, nor do they report it. Thus, they are not included in the analysis, even though if all their revenue from various sources would be summed up, some of them would have the obligation to pay taxes. Furthermore, this method is difficult to achieve if the tax evasion is widespread in a particular sector, business or profession group. Finally, it is difficult or almost impossible to determine the amount of undisclosed income more closely.

The analysis of opinions of experts for particular part of economy were used in the survey by Weck-Hannemann and Frey (1985). The authors started from the view that 
Switzerland is a small and open country, for which it will not be possible to obtain representative figures on volume and structure of the informal economy by randomly sampling through various household and labour force surveys. The reason is that it can be assumed that the most involved in this economy are the nonregistered foreign workers, who would not be included in the regular population survey. Therefore, they questioned the opinion of experts for certain activities or branches of the Swiss economy. In the questionnaire, sent by mail, they asked for personal assessment of the experts, not for the official opinion of the institution where they worked. The questions ask on the volume of the informal economy by activities and occupations, the share of full-time and part-time employees active in it, the number of weekly hours worked, and the share of foreign workers. Opinions were received from 26 experts from 13 institutions, with 21 responding to all questions. The authors emphasize that they are fully aware of the constraints related to this small sample as well as the inability to check and compare the obtained results with the control group. On the other hand, it can be surely assumed that the interviewed experts did not deliberately distort the data, which is usually the limit of similar direct methods of the informal economy estimation. After collecting and processing data, Hannemann and Frey assess that for Switzerland the share of the informal in the total economy was between 5 and $10 \%$ in agriculture, construction, catering, personal services, household and cleaning services, while between 2 and $5 \%$ in production of construction wood and furniture, trade, education, culture, entertainment and body care.

The method using very small enterprises (VSEs) as a proxy indicator of the magnitude of the unofficial economy has been applied by International Labour Organisation (2002a, 2002b), and US General Accounting Office (1989). However, this approach suffers from two contradictory presumptions. On the one side, not all very small enterprises are active in the unofficial economy, which could cause the overestimations in the assessments. On the other hand, fully unregistered very small enterprises can completely avoid government recordkeeping and could cause an underestimate in the obtained results (Williams, 2014). It also totally neglects more individualized forms of work in the unofficial economy performed by people on a one-to-one basis to satisfy final demand. Recent surveys by European Commission (2014) show that these types of activities present a large proportion of all work in the shadow economy in developed post-industrial countries.

A general disadvantage of direct methods is that they lead only to point estimates. Furthermore, probably they do not capture all shadow activities and can be used only for determining the lower bound of estimation. There are mostly incapable to provide estimations of the development and growth of the informal economy over the longer period. However, as mentioned, they can provide relatively detail insight into the informal economy and the structure and composition of the persons active in the informal work.

\section{Indirect methods}

A macro approach using the difference between revenues and expenditures on the level of the national economy is applied relatively often in assessing the size of the informal economy (Franz, 1992, Lovrinčević, Marić, Mikulić, 2006; Lovrinčević, Mikulić, Galić Nagyszombats, 2011, Mogelsen, 1992). The reason is not that such methods are deemed particularly useful in calculating estimates of GDP or in assessment of informal production, but because they tend to yield stunningly high shares of the grey economy, which attract much attention from politicians and media. However, there are serious almost unsolved problems with macro-model methods that 
challenge their fully utility for any intention where reasonable precision is essential. Some of its negative characteristics: the activities that the models aim to measure are not specifically defined and it is often not clear whether the models are estimating non-measured or non-observed production, or whether they include illegal activities or underground activities. Furthermore, the postulates included in the models are mostly simplistic and the obtained results are not stable in the sense that changes in postulates for the same model can obtain significantly different values. Thus, there are many models and they give different results, while the methods provide only a global estimate for the economy as a whole, whereas often the division of GDP by the economic sectors or expenditure category is needed. Finally, the results cannot be easily and simply combined with the results of other measurements, in particular those obtained in preparation of the national accounts (OECD, 2002).

A micro discrepancy analysis evaluates differences in expenditure and income through detailed microeconomic analyses of different types of individuals or households. This approach is based on the hypothesis that even if those engaged in the unofficial economy hide their earned incomes, they cannot conceal their expenditures. An evaluation of income/expenditure discrepancies supposedly reveals the extent of the unofficial economy and who does it. Such approach has been realised in various countries. In the United Kingdom, Dilnot and Morris (1981) compared the expenditures and income on a sample of households. The data on expenditures were from the Family Expenditure Survey, while the income data were obtained from tax forms. If expenditures are significantly and inexplicably higher than income, it was assumed that the difference between both figures is the hidden income. Although this method has advantages over other indirect methods, primarily because it is based on the use of relatively direct and statistically representative data, there are still many problems related to it (Thomas, 1988, 1992, Williams, 2014). For the discrepancy to represent a reasonable measure of the size of the informal economy there is a need to make a number of assumption about the exactness of the income and expenditure data.

Labour market approach by comparing the activity rates traces the shadow economy in formal labour force statistics and has two main varieties. The first method measures inexplicable increases in the numbers in different types of employment (for example, self-employment, second-job holding) as a proxy indicator of the size of the unofficial economy (Del Boca, Forte, 1982). However, the belief that unofficial work prevails in these categories of employment is an unconfirmed guess, rather than an established judgement. Thus, it is impossible to know the degree to which the unofficial work, rather than other factors, has led to such an increase. The second technique using labour force statistics search for discrepancies in the results of diverse official surveys, for example the population census and firm surveys (Contini, 1982, 1989, Flaming, Haydamack, Joassart, 2005). Contini (1982, 1989) used two estimating methods. In the first one, irregular labour force was defined as the difference between the official activity rate and that obtained in two ad hoc surveys. The official activity rate in Italy had dropped rapidly from a high level in 1959 and was well below that in other European countries. The ad hoc surveys in 1971 and 1977 were assumed to be correct. For 1977, a conservative estimate was that 17 percent of the total working population was engaged in irregular employment. The second approach assessed the unofficial labour force using numerous indicators. In manufacturing, the irregular labour force was estimated by at-home work; in building industry, mostly by multiple jobholders and those who officially were unemployed; and in services and trade, by multiple jobholders (many of whom 
worked in the public sector). The sum of these estimates was about one fifth of the total working population. Again, whether the variations identified are purely due to the unofficial economy or whether other survey design issues or factors are involved is difficult to discern. A third application of discrepancy methods is to compare the results of labour force surveys (LFS) with the recorded labour demand (for example, based on company declarations to national statistical offices and/or tax social security authorities). However, the problem with this approach is caused by the application of various sources of information, which may use not the same definitions, classifications and periods of measurement. Another disadvantage is that such discrepancy methods do not include particular sectors (for example, private households that function as employers or a part of agriculture) that may be particularly significant for unofficial work (Williams, 2014). Finally, regarding the sectors undeclared work is not everywhere of the same magnitude. There are significant variations in its size. The different estimates of undeclared work when measured in terms of total labour input and gross value added (GVA) is related mostly to the sectoral distribution of undeclared work and the varying productivity of sectors. A higher share of undeclared work in terms of GVA compared with total labour inputs suggests the concentration of undeclared work in sectors where labour productivity is higher. Concisely, broad application of these methods imply the need for a very strong and regular labour force survey. The methods can be applied for the estimation of the production in total within an economic activity branch, or just that part of production that is non-observed and/or non-obtained through enterprise surveys (OECD, 2002).

The monetary approach assumes that changes in the patterns of currency demand reflect accurately, and can be ascribed entirely to, changes in not included economic activities (OECD, 2002). Such methods can differ by (a) the fixed-ratio variant; (b) the currency-denomination variant; and (c) the currencyequation variant. The fixed-ratio variant lies on two crucial expectations. First, it presumes that a monetary ratio would have remained constant over time. If there is no the effect of the unofficial economy, Second, it presupposes that there was a golden past period without the underground economy (Tanzi, 1983). The monetary approach in measuring the unofficial economy starts from the point of view that most of the payments in it are done with cash, or very rarely through a check or payment order. This assumption, of course, is not entirely reliable.

When $C$ is currency in circulation, $D$ symbolises demand deposits, $M$ is money supply (made up of currency and demand deposits), $V$ is transactions (not income) velocity of money, and GNP is the officially estimated gross national product. According to the simple cash in circulation approach by Guttmann (1977), the unofficial economy is equal to monetary ratio between currency in circulation and demand deposit (C/D). Furthermore, total currency in the economy (C) consists of the part used for transaction in the official economy (Coe) and in the unofficial economy (Cue). In that way:

$$
\mathrm{C}=\mathrm{Coe}+\text { Cue }
$$

In the base period (b), there was no unofficial economy (Cue=0), so the relation between the currency and the demand deposits (D) was following:

$$
(C / D)_{b}=(\text { Coe/D })_{b}
$$

Without unofficial economy, a monetary ratio between currency and demand deposits would have remained constant over time (t):

In that way, we obtain:

$$
(\mathrm{Coe} / \mathrm{D})_{+}=(\mathrm{C} / \mathrm{D})_{+}=\text {constant }
$$

$$
\text { Coe }=(C / D) * D_{\dagger}
$$




$$
\mathrm{Cue}_{\dagger}=\mathrm{C}_{\dagger}-\mathrm{Coe}_{\dagger}
$$

We presume that the currency velocity $(\mathrm{V})$ is equal in both sectors:

$$
\mathrm{Voe}_{\dagger}=\mathrm{Vue}_{\dagger}
$$

From the monetary theory, it is known that the velocity speed is equal to the ratio between gross domestic product (GDP) and the total amount of money in circulation in the economy $(M)$ :

$$
\mathrm{V}_{\dagger}=\mathrm{GDP}_{\mathrm{t}} / \mathrm{MO}_{\dagger}
$$

In the unofficial economy is used the amount of money that has not been used in the official economy:

$$
\mathrm{Mue}_{\dagger}=\mathrm{M}_{\dagger}-\mathrm{Moe}_{\dagger}
$$

From the presented, follows the size of the unofficial economy (Suo) as:

$$
\begin{gathered}
\text { SuO }{ }_{t}=V_{\text {Vue }} * \text { Cue } \\
\text { SuO }_{t}=\text { Voe }_{+} *\left(C-(C / D)_{b}-D_{t}\right)
\end{gathered}
$$

The simple monetary approach generally overestimates the volume of unofficial economy. Buttler (1984) calculates the share of this phenomenon in GDP for USA in a scope from $3.4 \%$ to $33.0 \%$, Australia $10.0 \%$, Canada from $2.6 \%$ to $21.8 \%$, Italy from $9.6 \%$ to $30.1 \%$, Spain to $22.9 \%$, Sweden from $6.9 \%$ to $17.2 \%$, Norway from $6.4 \%$ to $16.0 \%$, UK from $7.2 \%$ to $16.2 \%$, and Germany from $2.0 \%$ to $27.0 \%$.

Transaction method the estimation of the unofficial economy by Feige (1979) is based on Fisher's equation of exchange (FEE). FEE compares the total volume of payments (MV) to the total volume of transactions (PT). If estimates of the volume of payments were in some way not related to the volume of transactions, then the difference between the two would provide a level of the unofficial economy. However, assessments of the total volume of transactions are difficult to obtain. Appraisals of the total volume of payments can be used as a proxy to assess the total volume of unrecorded income (Easton, 2001). $M$ is money, $V$ is velocity, $P$ is total number of transactions, while $P$ is the price of these transactions. Thus, the total stock of money (M) multiplied by the velocity of circulation (V) equals to the total number of transactions paid by such money $(T)$ multiplied by the price of these transactions (P).

$$
M * V=P * T
$$

Furthermore, it is expected that there is a constant relationship (symbolised by $k$ ) between the money flows related to these transactions and total value added, that is:

$$
\mathrm{P} * \mathrm{~T}=\mathrm{k}^{*} \text { Ytotal }
$$

where, by definition, total value added ( $Y$ total) is the sum of the official valued added ( $Y$ official) and the unofficial value added ( $Y$ unofficial). Hence

$$
\begin{gathered}
M^{*} V=k^{*} \text { (Yofficial }+ \text { Yunofficial) } \\
M_{+}^{*} V_{+}=k^{*} \text { (Y official }+Y \text { unofficial) }
\end{gathered}
$$

The stock of money (represented by currency plus demand deposits) is relatively easy to measure, money velocity can be assessed and the official assessments of value added are known. Thus, if the size of the unofficial economy as a ratio of the official economy is assumed to be known for a benchmark year, then the unofficial (underground) part can be estimated for all succeeding years. Feige (1979) used this method to the USA. He assessed the velocity of cash as the proportion of the number of transactions a greenback survives before being worn out and the average lifetime of greenback. The first part of this estimation was based on greenback wearing tests. He presumed that the unofficial economy was zero in 1939. According to these expectations he estimated the size of the unofficial economy as $27 \%$ of GDP in 1979. There are several serious problems with respect to the transaction method. The conjecture of a fixed ratio of transactions to official GDP seems unrealistic. It is 
quite possible that some pecuniary transactions that have nothing to do with income generation are included in the estimations. Obviously, a part of the money notionally in circulation, in particular banknotes of large denomination, is not actually in circulation but kept as a store of wealth. Additionally, the amount of money kept as cash depends upon inflation and interest rates as well as people's perception of the probability of being mugged. Increased facilities for and widespread use of various credit cards can also be expected to have had an essential impact (OECD, 2002). There are some additional problems in application of monetary methods to the economies of the post-transitional countries. These methods are not considered to take into account some of the phenomena which might occur in such economies, like high inflation, and therefore require modifications before they could be applied for those economies (Klarić, 2011).

The primary condition used in most monetary methods is that the velocity of currency in the unofficial economy is equal to the velocity of currency in the official economy that is quite questionable. Furthermore, the difficulty in the imputation of monetary values emerges because most household personal and domestic services are not produced for the market so that there are usually no appropriate market prices available to value them. Besides this valuation problem, it can be perceived that imputed values have in any case a different economic significance from the other monetary values.

Use of physical inputs method, like electricity, is often stated in the literature as the best estimator of overall and unofficial economic activities. Total economy activity and electricity consumption have been observed to be highly correlated in many countries around the world. The unobserved (unofficial) portion of the economy can be estimated by using electricity consumption as a proxy for total economic activity (official and unofficial). Withdrawing the growth of official GDP from the growth of electricity consumption provides an assessment of the increase of the unofficial economy. This method is analytically interesting, particularly for countries whose data collection is inadequate and/or lags behind the rest of the world. However, it can lead to both under- and over-estimation depending on the situation, development and trends of the observed economy. For instance, not all economic activities use electricity what causes underestimation of the unofficial economy. Furthermore, the developed post-industrial societies have achieved considerable organisational. technical and technological progress that increases the efficiency of the use of electrical energy, which again leads to underestimation of the unofficial economy. In addition, the relationship between the use of electrical energy and economic production is not a simple ratio, even in those industries that are highly dependent upon it, because a significant part (up to a third) of consumption is a fixed cost unrelated to the volume of production (OECD, 2002). For example, plants and offices need heating and lighting. This type of consumption tends to change in steps rather than increase smoothly with the growth of the production. The relationship between the electricity consumption and the GDP is of the questionable stability and this relationship is probably affected by a number of outside factors, like the climate conditions and weather. In many post-transitional countries there are no economic but artificial price levels what further endanger the relationship between industrial production and electricity consumption. In the conditions of relatively low electricity prices, manufacturers mostly do not worry about the exaggerated electricity consumption and do not try to lower the use of it when production descents. Finally, measurements of consumption are usually taken from the sources of electricity production at the power stations. In the most countries the difference between supply and final consumption - transmission losses - could be quite big. 
Additional electricity consumption method includes household electricity consumption. It is supposed that when household electricity consumption is high or with the tendency to grow, the underground economy will increase because a part of the household use of the electrical energy should be used for the informal economic activities. Household electricity consumption is assessed as a function of per capita real consumption, the price of consumption of one-kilowatt hour of electricity, the relative frequency of periods that require heating, the ratio of other household energy sources to the total of all energy sources and the per capita output of the informal economy (Easton, 2001). The disadvantages of the household electricity consumption approach are very similar to those by the estimation using electricity consumption by the economic entities. The problems with this method are threefold. First, not all kinds of informal work require a significant amount of electricity (for example, personal services). Second, other energy sources can be used (for example, coal, gas, oil). Third and most important, application of this approach to measure temporal changes does not take into account improvements and increases in energy efficiency or how alterations in the elasticity of electricity-to-GDP differ across countries and over time (Andrews, Caldera Sanchez, Johansson, 2011). The household electricity approach is not so seriously affected by political and economic transition, but still is has a limited scope to non-registered activities consuming household electricity.

\section{Causal methods}

The approach changes in demand for cash for the estimation of the unofficial economy is based on the belief that such transactions are mostly paid in cash. Thus, if mentioned demand increases, also the unofficial economy should rise. However, this assumption cannot be tested and may not be true. Tanzi (1983) assumed that the demand for cash money was not only under the influence of government regulation and taxation, but it is also affected by other factors. However, he believes that changes in the total amount of money in cash due to changes in government regulation and taxation go totally into the unofficial economy. To isolate the impact of regulation and taxation, Tanzi assumed that the demand for cash as a proportion of total money, C/M2 (where M2 is cash money + transferable money + fixed period deposits), is a function of the share of wages and salaries in total personal income, taxes, per capita real income, and the interest on fixed term deposits. According to the results of regression analyses, Tanzi obtained two alternative assessments of the notional demand for cash money (defined as the demand for cash money on the supposition that there is only the official economy). In each case, the difference between the actual demand and the hypothetical demand was deemed to be the total amount of cash money in the informal economy (OECD, 2002). Supposing the equal velocities of cash money in the formal and the informal economy, the estimated size of the underground economy in the USA in 1976 was 3.4-5.1\% of GNP according to the first variant and little bit higher $8.1-11.7 \%$ according to the second variant (Tanzi, 1983). Some other surveys showed that both cash/deposit and cashdemand methods can bring counter-intuitive results. In the analysis for the Netherlands, the results presented a decreasing underground economy since the end of the 1970s, which is in contradiction to the generally accepted belief that the non-registered economy was increasing (OECD, 2002).

The DYMIMIC (dynamic multiple indicators multiple causes) method seeks to overcome some of the problems of the earlier mentioned approaches by considering multiple indicators and multiple causes (Schneider, 2005, 2011, 2013, Schneider, Enste, 2000). In this method, the shadow economy is an unobserved (or 
latent) variable that influences observed indicators and is determined by observed variables. Schneider (2001) analyses the causes of the shadow economy as the burden of direct and indirect taxation (both actual and perceived), the burden of regulation and tax morality (citizens' attitudes towards and willingness for paying taxes). In the further development, this method includes and examines the additional determinants and indicators (male participation rate, hours worked and growth of real Gross National Product). Using the econometric tools, it calculates the size of the unofficial economy. This method is complex and requires powerful analytical tools for its use, but it can be efficiently applied to assess the size and the characteristics of the informal economy in a small open economy (Novkovska, Dumičić, 2017). A most important limitation of this method is that it only provides information on the relative size of the underground economy. Extensive explanation of the model, its limit and application is available by Klarić (2011), so there is no need to reiterate it. The reason why the application of DYMIMIC to the estimation of the unofficial economy is so appealing is that this approach appears to provide both the estimate of the phenomenon and its relationship to other variables. However, it is possible to challenge all of these mentioned causes and indicators. It looks that there is limited understanding that included factors per se are not crucial but rather how they are combined with a plethora of others factors, that causes high or low levels of non-registered work. Moreover, many of the indicators used are questionable. For example, numerous studies reveal that cross-national variations in taxation rates, whatever measure of taxation is used, are either not correlated with the underground economy or the association is not in the direction expected in this model (Eurofound, 2013, Williams, 2014). Similarly, studies reveal that one cannot assume that the burden of regulation per se results in an increase in the size of the shadow economy. Although some forms of regulation, such as the stricter regulations on temporary employment and temporary work agencies, usually lead to larger unofficial economies, other types of regulation, such as support for new business start-ups, are not associated with increased underground economies (Williams, Renooy, 2013). Thus, there is a need for careful use of this measurement approach and it is perhaps the case that a more demanding multiple indicators method is required.

\section{Eurostat approach}

Taxonomy of non-exhaustiveness types in the national accounts is based on the analysis of various features of the producer. The tabular approach to exhaustiveness (TAE) was developed to identify potential sources of underestimation of GDP due to source data, based on two main approaches: producer is not included into the survey, and producer is included into the survey but data is not adequate. The TAE classifies non-exhaustiveness types under seven diverse types N1 to N7. Some types of non-exhaustiveness in the national accounts could be categorised under various $\mathrm{N}$-types. For instance, an informal sector unit could be categorised under either of N3, N4 or N5. Thus, the crucial intention in the tabular approach to exhaustiveness is to ensure that all potential sources of omission and errors from the national accounts are recognised and included in one or other N-type categories. Also is important that there is no double accounting (duplication) across categories. Exhaustiveness of national accounts has been defined by making use of producers' features and data sources used for the production approach. A producer may not be included into the surveys/administrative source because he or she fails to register as he or she is involved in underground (N1) or illegal (N2) activities; or it is not obliged to register (household non-market producers) (N3). Furthermore, it is possible that he or she is a 
legal person but is not surveyed and not included in statistics (N4); or it is a registered entrepreneurship - legal person but it is not surveyed (N5). Furthermore, producers are in scope of surveys and/or administrative source, but the resulting data may not be suitable because the producer deliberately misreports (N6); or there are statistical insufficiencies and/or errors in the data (N7). Therefore, some data are simply not collected (N7a), or some data are not appropriately processed (N7b). Identification and adjustment methods vary for different types of non-exhaustiveness. For example, by N3, adjustment methods for producers with no market output includes the analysis of household expenditure surveys, commodity-flow methods, building permits, administrative data and time use surveys. For producers with market output there is a need to use Informal sector surveys, household surveys, mixed household and establishment surveys and labour input methods. Those registered units which are included into the surveys because of the size criteria (mostly employment) or other conditions (omission of specific activities from the surveys) (N4), can be included through benchmark (for example, once in 5 or 7 years) surveys for gathering a set of benchmark estimates. Furthermore, mixed household and enterprise surveys and labour input methods as well as household surveys, can provide estimates through direct or indirect methods, if relevant items for identification of such units is included in these surveys. TAE is based on the European developed country experiences of collecting national accounts and the principal data sources (financials statements, industry surveys, etc.) (Mikulić, Galić Nagyszombaty, 2013).

The non-exhaustiveness component in these countries is usually not large (OECD, 2002). Such comprehensive data sources for compiling national accounts may not exist in post-transitional countries where the informal sector is a large part of nonexhaustiveness. From the point of data collection, the most important division is into own account firms (self-employed workers), business activities engaged in production for own use, and other business organizations. In most countries, the legal status and legal requirements for own account enterprises differ considerably from those for other enterprises (Lovrinčević, Marić, Mikulić, 2006). For instance, the book keeping requirements are less stern and business and private book-keeping is usually combined. Enterprises engaged in production for own use are not required to keep books, so their available data are usually less detailed than those from other enterprises. It looks like that for Croatia according to type of non-exhaustiveness, the most significant is N6 type (inaccurate reporting by producers). Its average share is $72 \%$ of total non-exhaustiveness adjustments (Galić Nagyszombaty, 2012).

Although this method is relatively complicated and demands many arbitrary estimates, it is quite reliable and enables sectoral and international comparison. Models often buttress other methods used in compilation, providing assessments when basic data are not available and/or are not fully reliable. This is usually the case, for example, in making estimates of illegal production. If a country plans to achieve exhaustiveness in GDP, priority should be given to better inclusion for informal sector in national accounts (Calzaroni, 2000). This should be obtained with use of the ad hoc surveys, commodity flow methods, labour input methods, and expert estimates. More resource intensive methods such as the tax audits, surveys for estimating underground production and misreporting, could be used depending upon the availability of resources.

\section{Grey Project}

Having in mind the advantages and disadvantages of the various methods, in the Grey Project mostly direct methods - interview and focus groups discussion - were 
used with the intention to get an insight in the reasons for participation in the informal economy and proposals for its reduction. The presented data are from representative survey of 6,019 citizens in Croatia, Bulgaria and FYR of Macedonia (approximately 2,000 individuals in each country); conducted during the period Spring-Summer 2015. This survey was collected using the face-to-face methodology (TAPI - Tablet Assisted Personal Interview) by highly trained and experienced professional interviewers using a multi-stage stratification proportionate to population sample distribution, with random selection of households and respondents. Furthermore, 30 qualitative interviews with under-declared (quasi-formal) workers in Croatia were realised during spring 2015 and 9 interviews with experts during spring 2016.

According to Stefanov, Williams and Rodgers (2017a), unofficial work is socially accepted and widely practiced in Bulgaria, Croatia, and the FYR of Macedonia. More than 1 in 5 interviewed adults in these countries admit that they have bought goods and services on the unofficial economy in the previous year. There are three broadly accepted and competing explanations for consumers purchasing goods and services in the undeclared economy, mostly to obtain good or services by a lower price. More than 1 in 12 report that they have performed undeclared work, and more than 1 in 10 declared employees admit that they receive from their employer in addition to their official salary an additional undeclared 'envelope' wage (Table 2).

Table 2 Pervasiveness of illegitimate economic practices, in \%

\begin{tabular}{|l|c|c|c|}
\hline & Croatia & Bulgaria & $\begin{array}{c}\text { FYR of } \\
\text { Macedonia }\end{array}$ \\
\hline Buying undeclared goods & 16.5 & 17.3 & 13.8 \\
Paying for services under-the-table & 20.4 & 22.2 & 13.3 \\
Conducting undeclared work & 9.4 & 9.8 & 6.4 \\
Quasi-formal employment & 6.8 & 15.5 & 13.9 \\
Relying on help and favours from other people & 31.7 & 30.1 & 37.8 \\
Providing help/favours to other people & 15.9 & 14.8 & 24.3 \\
\hline
\end{tabular}

Source: Authors' own calculations based on the representative survey of 6,019 individuals in Croatia, Bulgaria and FYR of Macedonia.

More than 4/5ths of those working in the undeclared economy do so on a selfemployed basis. Only $17 \%$ in Bulgaria and FYR of Macedonia and $13 \%$ in Croatia have declared they have done so as part of waged employment for business (Williams, Bezeredi, 2017).

However, clandestine work differs across and within the three countries. For every one person working clandestine due to exclusion from the formal economy, there are three persons that have chosen to exit the formal economy. This also differs across observed countries. While quasi-formal employment is relatively rare in Croatia, it is more often in Bulgaria and FYR Macedonia. While $20.4 \%$ of Croat and $22.2 \%$ of Bulgarian are paying for services under-the-table, in FYR of Macedonia this share is significantly lower (13.3\%) (Stefanov, Williams, Rodgers, 2017b).

Demographic characteristics of people working in the informal economy show that they are slightly younger and with higher percentage of male. These people work longer hours at job and at home and on private farms. They usually know more people who are also a part of the unofficial economy, while they are more relaxed (not judgmental) towards morale issues in society. Regarding their well-being their subjective feeling of happiness is slightly lower, but self-esteem is not lower in 
comparison with total population (Stefanov, Williams, Rodgers, 2017a). Franic and Williams (2017) underline that demand for undeclared goods and services is induced mostly by values and perceptions of citizens. The most important drivers are tax morale and estimated pervasiveness of the phenomenon in society.

\section{Conclusions and recommendations}

Obviously, each one of the mentioned methods has its strengths and weaknesses and each of them lights or evaluates a various aspect of the informal economy. It follows that it is useful to profit from the variety of approaches provided by various measurement methods, and to try to apply each one of them in order to expose a different characteristics feature of the informal economy.

Since their membership of the EU, Bulgaria and Croatia have enjoyed considerable financial and technical aid from the European Union and partner countries, which has resulted in considerable improvement in their overall policy environment. In their further efforts to reduce the informal economy, an important consideration for all governments from the region is to begin to develop holistic strategies for tackling the undeclared economy. For successful achievement of the desired goals, the government need to engage adequately all stakeholders in the preparation, implementation, and evaluation of policy measures.

One of the more underrated probable causes of policy failure has been the apparent lack of knowledge and understanding of the needs, attitudes and abilities of policy beneficiaries and target groups. Deciding on the proper combination of policy measures as well as on the transferability of best practices within Europe, requires further understanding of the guiding motivations and potential responses to policy measures by the subjects engaged in the undeclared economy on the demand- and supply-side. GREY data research has provided policy insights in each of the countries and for the region altogether. Findings on both sides have reinforced each other.

GREY research has revealed a number of contextualising factors in the three observed countries. These factors probably will be obstacles to successful implementation of future measures. What is typical for all three observed countries is that in order for more targeted measures towards the informal economy to be successful, there is a need to strengthen significantly the broader institutional foundation. This could be achieved by strengthening the rule of law, enhancing government efficiency, reducing and limiting corruption, and increasing the legitimacy and transparency of public institutions overall. Simultaneously, there is a need to improve the quality of public goods, restore and strengthen social solidarity and reduce inequality. Policymakers should consider not just the rational but also the social actor approach, which tackles trust issues and the asymmetry between formal and informal rules. The conventional repressive approach to tackling undeclared work has exhausted its effects. All such measures are needed in reduction of the relatively wide gap between citizens and the state.

Succinctly, from all sources it is obvious that it is much better to obviate the causes than penalise the consequences. It is necessary to simplify the procedures for citizens' formalizing their undeclared activities, to insure a stable tax system and a tax and regulatory burden as low as possible, having in mind the fiscal needs. Crucial is the improvement of institutions, professionalization of civil service and remove the huge impact of politics in the societies. All mentioned cannot be achieve in the short term, but the trend in the right direction is a huge step forward. 


\section{References}

1. Andrews, D., Caldera Sanchez, A., Johansson, A. (2011). Towards a Better Understanding of the Informal Economy. OECD Economics Department Working Paper, No. 873, pp. 145.

2. Bajada, C. (2002). Australia's Cash Economy: A Troubling Issue for Police-makers. Ashgate, Aldershot.

3. Buttler, G. (1984). Schattenwirtschaft - Grenzen der Erfassbarkeit, Schattenwirtschaft: Grenzen d. Erfassbarkeit. Beiträge zur Wirtschafts- und Sozialpolitik 120/121, Deutscher Institut - Verlag, Köln.

4. Calzaroni, M. (2000). The Exhaustiveness of Production Estimates: New Concepts and Methodologies. Available at https://www.oecd.org/std/na/2464056.pdf [09 October 2017].

5. Contini, B. (1982). The Second Economy of Italy. In The Underground Economy in the United States and Abroad, Tanzi, V. (Ed.), Lexington Books, Lexington, pp. 131-159.

6. Contini, B. (1989). The irregular economy of Italy: a survey of contributions. In The underground economies: Tax evasion and information distortion, Feige, E. (Ed.), Cambridge University Press, Cambridge.

7. Del Boca, D., Forte, F. (1982). Recent empirical surveys and theoretical interpretations of the parallel economy in Italy. In The Underground Economy in the United States and Abroadi, Tanzi, V. (Ed.), Lexington Books, Lexington, pp. 160-178.

8. Dilnot, A., Morris, C. N. (1981). What Do We Know About the Black Economy?. Fiscal Studies, Vol. 2, No. 1, pp. 58-73.

9. Easton, S. (2001). The Size of the Underground Economy: A Review of the Estimates, Available https://www.researchgate.net/publication/251857713_The_Size_of_the_Underground_Ec onomy_A_Review_of_the_Estimates [09 October 2017].

10. Eurofound (2013). Tackling Undeclared Work in 27 European Union Member States and Norway: approaches and measures since 2008. Eurofound, Dublin.

11. European Commission (2014). Special Eurobarometer 402: Undeclared Work. European Commission, Brussels.

12. Feige, E. L. (1979). How Big is the Irregular Economy?. Challenge, Vol. 22, No. 1, pp. 5-13.

13. Feige, E. L. (1990). Defining and Estimating Underground and Informal Economies: The New Institutional Economics Approach. World Development, Vol. 18, No. 7, pp. 989-1002.

14. Feige, E. L., Urban, I. (2003). Estimating the Size and Growth of Unrecorded Economic Activity in Transition Countries: A Re-evaluation of Electric Consumption Method Estimates and their Implications. Available at http://econwpa.repec.org/eps/mac/papers/0311/0311010.pdf [09 October 2017].

15. Flaming, D., Haydamack, B., Joassart, P. (2005). Hopeful Workers, Marginal Jobs, LA's Offthe-Books Labour Force. Available at https://economicrt.org/publication/hopefulworkers-marginal-jobs [09 October 2017].

16. Franic, J., Williams, C. C. (2017). Illegitimate Economic Practices in Croatia Findings from a representative survey of 2,000 citizens. GREY Working Paper, No. 9, pp. 1-151.

17. Franz, A. (1992). Estimates of the Hidden Economy in Austria on the basis of Official Statistics. In Guide Book to Statistics on the Hidden Economy, United Nations, Economic Commission For Europe, Statistical Division, Geneva, New York, pp. 67-78.

18. Galić Nagyszombaty, A. (2012). Unofficial economy in Croatia: Estimation methods and results, Methods and Results. Ekonomski pregled, Vol. 3, No. 1, pp. 734-762.

19. Hansson, I. (1980). Sveriges svarta sektor. Ekonomisk Debatt, Vol 6. No. 8, pp. 595-602.

20. Hansson, I. (1982). The Underground Economy in a High Tax Country: The Case of Sweden. In Tanzi, V. (eds.) The Underground Economy in the United States and Abroad, Lexington Books, Lexington, pp. 233-243.

21. International Labour Organisation (2002a). Decent work and the informal economy. International Labour Organisation, Geneva.

22. International Labour Organisation (2002b). Women and men in the informal economy: $A$ Statistical Picture. International Labour Organisation, Geneva. 
23. ISTAT (2016). L'economia non-oservata nei conti nazionali (2011-2014). Available at http://www.bollettinoadapt.it/wp-content/uploads/2016/10/Economia-nonosservata_2014.pdf [9 October 2017].

24. Kazemier, B. (1991). Concealed Interest Income of Households in the Netherlands: 1977, 1979 and 1981. Public Finance, Vol. 46, No. 3, pp. 443-453.

25. Klarić, V. (2011). Estimating the Size of Non-Observed Economy in Croatia Using the MIMIC Approach. Financial Theory and Practice, Vol. 35, No. 1, pp. 59-90.

26. Lovrinčević, Ž., Marić, Z., Mikulić, D. (2006). Maastrichtski kriteriji i uključivanje sive ekonomije - slučaj Hrvatske. Privredna kretanja i ekonomska politika, Vol. 16, No. 106, pp. 28-65.

27. Lovrinčević, Ž., Mikulić, D., Galić Nagyszombaty, A. (2011). Unofficial Economy in Croatia and the Impact of the Economic Recession on the Unofficial Economy". In Challenges of Europe: Growth and Competitiveness - Reversing the Trends, Grčić, B. (Ed.), University of Split, Faculty of Economics, Split, pp. 479-508.

28. Mikulić, D., Galić Nagyszombaty, A. (2013). Causes of the unofficial economy in new EU member states. Ekonomska istraživanja - Economic Research, No. Special Issue 2013, pp. $1-16$.

29. Mogelsen, G. V. (1992). Black Markets and Welfare in Scandinavia: Some Methodological and Empirical Issues, In Guide Book to Statistics on the Hidden Economy, Economic Commission for Europe, Statistical Division, United Nations, Geneva, New York, pp. 177185.

30. Novkovska, B., Dumičić, K. (2017). Modelling of temporal patterns of hidden economy in connection with energy consumption. In Proceedings of the 14th International Symposium on Operational Research SOR'17, Zadnik Stirn, L., Kljajić Borštnar, M., Žerovnik, J., Drobne, S. (Eds.), Slovenian Society Informatika, Section for Operational Research, Bled, September 27-29, 2017, pp. 47-52.

31. OECD (2002). Measuring the Non-observed Economy Handbook. Available at https://www.oecd.org/std/na/1963116.pdf [09 October 2017].

32. Roever, S. (2014). Informal Economy Monitoring Study Sector Report: Street Vendors. Available at http://www.wiego.org/sites/default/files/publications/files/IEMS-Sector-FullReport-Street-Vendors.pdf [09 October 2017].

33. Schneider, F. (2001). What do we know about the shadow economy? Evidence from 21 OECD Countries. World Economics, Vol. 2, No. 4, pp. 19-32.

34. Schneider, F. (2005). Shadow Economies around the World: What Do We Really Know? European Journal of Political Economy, Vol. 21, No. 3, pp. 598-642.

35. Schneider, F. (2011). Handbook on the Shadow Economy. Edward Elgar Publishing, Cheltenham.

36. Schneider, F. (2012). The Financial Flows of Transnational Crime and Tax Fraud in OECD Countries: What Do We (Not) Know? Available at http://www.econ.jku.at/members/Schneider/files/publications/2012/FinancialFlows_TaxFr aud.pdf [09 October 2017].

37. Schneider, F. (2013). Size and development of the shadow economy of 31 European and 5 other OECD countries from 2003 to 2013: a further decline. Available at http://www.econ.jku.at/members/Schneider/files/publications/2013/ShadEcEurope31_Ja n2013.pdf [09 October 2017].

38. Schneider, F., Enste, D. (2000). Shadow Economies around the World: Size, Causes, and Consequences. Available at https://www.imf.org/external/pubs/ft/wp/2000/wp0026.pdf [09 October 2017].

39. Smith, S., Wied-Nebbeling, S. (1986). The Shadow Economy in Britain and Germany. Anglo-German Foundation for the Study of Industrial Society, London.

40. Stefanov, R., Williams, C. C., Rodgers, P. (2017a). Tackling Undeclared Work in Southeast Europe: Knowledge-Informed Policy Responses. GREY Policy Brief, No. 4, pp. 1-15.

41. Stefanov, R., Williams, C. C., Rodgers, P. (2017b). Tackling Undeclared Work in the FYR of Macedonia: Knowledge-Informed Policy Responses. GREY Policy Brief, No. 2, pp. 1-10.

42. Tanzi, V. (1983). The Underground Economy in the United States: Annual Estimates, 193080. IMF-Staff Papers, Vol. 30, No. 2, pp. 283-305. 
43. Thomas, J. J. (1988). The politics of the black economy. Work, Employment and Society, Vol. 2, No. 2, pp. 169-190.

44. Thomas, J. J. (1992). Informal economic activity. Harvester Wheatsheaf, Hempstead.

45. US General Accounting Office (1989). Sweatshops in New York City: A Local Example of a Nationwide Problem. US General Accounting Office, Washington.

46. US Internal Revenue Service (1979). Estimates of Income Unreported on Individual Income Tax Returns. Government Printing Office, Washington.

47. Weck-Hannemann, H., Frey, B.S. (1985). Measuring the Shadow Economy: The Case of Switzerland. Available at https://link.springer.com/chapter/10.1007\%2F978-3-642-884085_6 [09 October 2017].

48. Williams, C. C. (2014). Confronting the shadow economy: evaluating tax compliance and behaviour policies. Edward Elgar, Cheltenham.

49. Williams, C. C., Renooy, P. (2013). Tackling undeclared work in 27 European Union Member States and Norway: Approaches and measures since 2008. Available at https://www.eurofound.europa.eu/sites/default/files/ef_publication/field_ef_document/ ef1324en3.pdf [09 October 2017].

50. Williams, C., Bezeredi, S. (2017). Evaluating Policy Approaches towards Undeclared Work: Some Lessons from FYR Macedonia. GREY Paper, pp. 1-15.

\section{About the authors}

Predrag Bejaković is employed the Institute of Public Finance, Zagreb. He was a Fulbright scholar at the University of Wisconsin at Madison, and a British Council Scholar at Essex and Bath Universities. He has taken part in a number of projects, such as The Underground Economy and Pensions Reform. He publishes in scientific and professional journals and he is author and co-author of a number of books from the areas of the economy, education (particularly VET and adult education), public finance, underground economy and labour economics. His main fields of interests are labour economics, education, social policy, poverty reduction and economic development. Recently he was a team leader for Croatia for the Project Grey related to the underground economy. Lately he published "The Evasion of Retirement Insurance Contributions in Croatia" in the Studies of Transition States and Societies and "A revision of the shadow economy in Croatia: causes and effects" in Ekonomska istraživanja. Author can be contacted at: predrag.bejakovic@ijf.hr. 